\title{
Effect of Voluntary Disclosure on Earning Response, Controlling for Profitability, Leverage and Size
}

\author{
Cheng Fan Fah and Tan Suai Huei \\ Department of Accounting and Finance, Faculty of Economics and Finance, \\ University Putra Malaysia.
}

\begin{abstract}
This study aims to investigate the effect of voluntary disclosures on earnings response and company performance in Malaysian listed companies, controlling for profitability, leverage and size. The study uses a disclosure index adopted by Botosan (1997) to measure the scope of voluntary disclosure; the earnings response coefficient (ERC) measures the regression of abnormal return and unexpected earnings; and company performance such as profitability, leverage and size of company is also measured. The results concluded that voluntary disclosure has a positive effect on the earnings response coefficient (ERC). Also, unexpected earnings has a significant positive effect on earnings response coefficient (ERC). This study explains the effect of expected voluntary disclosure on investor reaction.
\end{abstract}

Keywords: Voluntary disclosure, earnings response coefficient (ERC), company performance

\section{INTRODUCTION}

A company provides information through its annual report. An annual report is the most essential source of information of a company to report and disclose all the year's activities or business affairs; the financial condition and future prospects of the company are summarised therein. Information in the annual report is either mandatory disclosed or and voluntarily disclosed. Mandatory disclosure refers to the information that required to be disclosed by the Corporation Law, Accounting Standards and Listing Rules of Stock Exchange as practised by the country. Voluntary disclosure refers to all the information which a company voluntarily provides in their annual report such as chairman's statement, board of directors, management committee, performance review, company's future prospects and company's operation review. This information is useful to the shareholders, management, and the preparers and users of accounting information in assessing the stewardship for resources entrusted to them in order to make economic decisions which are prudent, effective and efficient.

Under the growing of awareness for transparency in reporting, Malaysian regulatory authorities and professional accounting bodies encourage companies to go beyond the mandatory disclosure in company reporting for the past few decades through the establishment of the National Corporate Reports Awards (NACRA) which is jointly organised by the Malaysian Institute of Accountants (MIA), Malaysian Association of Certified Public Accountants (MACPA), Kuala Lumpur Stock Exchange (KLSE) and the Malaysian Institute of Management (MIM). Previous studies focus strongly on the association between the level of voluntary disclosure and company characteristics. This study aims to examine the effect of voluntary disclosure on earning response. Moreover, this study investigates the extent of disclosure on company performance and attempts to explain the relationship between them. 
This study is organised into five sections. Section 2 discusses voluntary disclosure, earnings response and company performance literature based on theoretical and empirical studies, the relationship between voluntary disclosure and earnings response; and the relationship between voluntary disclosure and company performance. Section 3 explains the research methodology, sampling method, data collection and the measurement of all variables used. Section 4 indicates the findings and results of the study and the explanation of the results obtained. Section 5 presents the conclusions.

\section{LITERATURE REVIEW}

Cooke $(1989,1992)$ describes voluntary disclosure as the additional information to that of the mandatory information, which has substantially increased over the last few decades. Such disclosure may support and sustain a healthy demand for shares and any disclosure related to the companies' operations may influence the stakeholders and investors in their investment decisions. Meek et al. (1995) explained voluntary disclosure as "disclosure in excess of requirements - represent free choices on the part of company management to provide accounting and other information deemed relevant to the decision needs of users of their annual reports". Alan (2001) emphasised that companies provide voluntary information by giving enhanced information that aids investors and creditors to understand the company better.

Research by Lang and Lundholm $(1993,1996)$ showed that a greater level of disclosure was related with better market performance (as measured by stock return). Lang et al. (1993) used the correlation of income and stock return asymmetry as proxy information, which is consistent with the pattern of adverse selection. The correlation between income and stock return was noted to be low; this implied a high level of information asymmetry. Hence, disclosure information aims to reduce information asymmetry. Thus, Lang et al. (1993) expressed that there is a negative relationship between correlations of earnings response coefficient (ERC) to the level of disclosure.

Earnings response coefficient (ERC) is the coefficient which measures the response of abnormal returns to unexpected earnings of companies that issue securities. Earnings response coefficient (ERC) can measure the ratio of abnormal stock returns divided by unexpected earnings. Profit information is an essential information shown in the annual report (Lev, 1989). In other words, an earnings reported has the power of response. Strong market reaction to earnings information will lead to a high earnings coefficient (ERC), and the reverse holds true. Thus, a high or low earnings response coefficient relies on the information disclosed on returns or earnings. According to Scott (2000), the earnings response coefficient (ERC) measures the stock returns in response to unexpected earnings reported by a company; in other words there is a variation in the association between profits of a company with its stock return.

Cho and Jung (1991) stated that empirical studies on earnings response coefficient (ERC) can be divided into two groups: (1) research about the factors that affect earnings response coefficient (ERC) and which measure the earnings response coefficient (ERC) as an association between accounting profit with stock return in the long term without making any association with some events, and (2) research that relates to accounting profit information to investigate the effect of some events to earnings response coefficient (ERC) in the short term. Thus, earnings response coefficient (ERC) can used to estimate future accounting profit as well as its quality of accounting profit. Prior studies by Widiastuti (2002) investigated the relationship between extensive voluntary disclosures to current earnings response coefficient (ERC) and noted that the former has a positive effect on the latter. This was consistent with that of Gelb and Zarowin (2000) and Adhariani (2005).

Sayekti (2007) examined the effect of disclosure on earnings response coefficient (ERC) and concluded that the level of disclosure in annual reports has a negative effect on company's earnings response coefficient (ERC). These results can be explained by the fact that investors appreciate the information disclosed in the annual report and hence such disclosures have a positive impact on the company. Francis 
et al. (2008) found that companies with good earnings quality provide a larger quantity of voluntary disclosure in their annual reports and 10Ks than companies presenting poor earnings quality. Ariff and Cheng $(2011,2013)$ studied the ERC in ASEAN Banks for their 2011 study and thereafter in OECD countries for their 2012 study, with additional variables. Their studies proved the significance of ERCs and explains the reaction of share prices during earnings announcements.

\section{RESEARCH METHODS}

This study focuses on the effect of voluntary disclosure on earnings response and company performance for the years 2009 to 2013. 30 companies were selected from the construction, consumer product, industrial product, trading or services and properties industry in the Main Market of Bursa Malaysia.

\subsection{Variables Measurement}

This part presents the measurement of voluntary disclosure, earnings response coefficient (ERC) and company performance as below.

\subsubsection{Earning response coefficient (ERC) and Voluntary Disclosure}

In this section, the measurement of the level of voluntary disclosure is based on that adopted by Botosan (1997), who noted that the annual report was the most essential aspect of corporate information to the disclosure index (Botosan, 1997). The voluntary disclosure index is weighted based on five categories which included background information, summary of historical results, key non-financial statistics, projected information, and management discussion and analysis. The measurement of earning response coefficient (ERC), $b$ is a response of accounting profit from the regression between the returns $(\mathrm{R})$ and the unexpected earnings (UE). The equation of earnings response coefficient (ERC) is as follows:

$$
R_{i t}=a+b\left(U E_{i t}\right)+e_{i t}
$$

The next equation shows the summary list of variables, their description and their relationship in the regression. The regression model below is used to test the effect of voluntary disclosure on earnings response:

$$
R_{i t}=a+b\left(U E_{i t}\right)+c\left(\operatorname{VDSCORE} E_{i t}\right)+e_{i t}
$$

Where:

$\mathrm{R}=$ Return

$\mathrm{a}, \mathrm{b}, \mathrm{c} \quad=$ Coefficient of respective independent variables

UE $\quad=$ Unexpected earnings

VD SCORE $\quad=$ Voluntary disclosure score

Controlling for size, leverage and profitability:

$$
R_{i t}=a+b\left(U E_{i t}\right)+c\left(\operatorname{VDSCORE} E_{i t}\right)+d\left(\operatorname{PROFIT}_{i t}\right)+e\left(L E V_{i t}\right)+f\left(\operatorname{SIZE}_{i t}\right)+e_{i t}
$$

Where:

PROFIT = Profitability $=$ Return on Equity

LEV = Leverage $=$ Logarithm of the ratio of long term debt to total equity

SIZE $=$ Size of company $=$ Logarithm of total assets 


\subsection{Research Hypothesis}

The objective of the study is to investigate the effect of voluntary disclosure on earnings response, the effect of voluntary disclosure on company performance and the effect of voluntary disclosure and company performance on earnings response. Thus, the following hypotheses were developed:

$\mathrm{H}_{0} 1$ : Unexpected earnings and voluntary disclosure do not have a significant relationship with earnings response.

$\mathrm{H}_{1} 1$ : Unexpected earnings and voluntary disclosure do have a significant relationship with earnings response.

\section{RESULTS}

\subsection{Descriptive Statistics}

The following Table 1 presents the descriptive statistics of all the measuring variables for the 30 samples; the highest return is noted to be 2.00 and the lowest return is 0.00 , with an average value 0.49 with a standard deviation of 0.417 . The average of unexpected earnings (UE) is 0.35 with maximum earnings of 4.00, minimum earnings of -1.00 and standard deviation of 1.07 . The overall results of the voluntary disclosure score (VD score) indicate that the maximum score is 0.72 , the minimum score is 0.28 , and the mean value is 0.45 with a standard deviation of 0.11865 .

The profitability ratio exhibits the ratio of net income to total equity, with an average value of 0.0823 , and highest and lowest ratios of 0.27 and -0.17 respectively. Meanwhile, the maximum and minimum value of leverage (logarithm of long term debt to total equity) is 0.41 and - 0.93 respectively with an average of -0.1026 and standard deviation of 0.32895 . The size of company (logarithm of total assets) shows an average of 5.6233 with standard deviation of 0.63154 , and the maximum and minimum values of 6.79 and 4.05 respectively.

Table 1: Descriptive statistics

\begin{tabular}{lrrrrr}
\hline Variable & $\mathbf{N}$ & Minimum & Maximum & Mean & Standard Deviation \\
\hline R & 150 & 0.00 & 2.00 & 0.49 & 0.417 \\
UE & 150 & -1.00 & 4.00 & 0.35 & 1.07 \\
VD score & 150 & 0.28 & 0.72 & 0.45 & 0.11865 \\
PROFIT & 150 & -0.17 & 0.27 & 0.0823 & 0.08208 \\
LEV & 150 & -0.93 & 0.41 & -0.1026 & 0.32895 \\
SIZE & 150 & 4.05 & 6.79 & 5.6233 & 0.63154 \\
\hline
\end{tabular}

$\mathrm{R}=$ return; $\mathrm{UE}=$ unexpected earnings; VD score $=$ voluntary disclosure score; PROFIT $=$ profitability; LEV $=\log$ (leverage) $;$ SIZE $=$ Log (size of company)

\subsection{Test the Effect of Voluntary Disclosure on Earnings Response}

We refer to the linear regression model developed to test the effect of voluntary disclosure on earning response. The dependent variable is return $(\mathrm{R})$ and the independent variables are unexpected earnings (UE) and voluntary disclosure score (VD Score).

From Table 2 below, models 1 and 2 present the regression which regress one independent variable at each time, however, model 3 is the final regression which includes all the independent variables. Model 1 indicates the coefficient of unexpected earning (UE) with $b=0.165$, t-statistic $=2.479$ and $p$-value $=0.019$. 
The regression results of earnings response and unexpected earning (UE) are significant. This means that there is a positive relationship between earnings response and unexpected earning (UE). The R-square of model 1 is 0.180 which implies that the effect of unexpected earning (UE) on earnings response is $18 \%$. Thus, the regression equation for model 1 is $\mathrm{R}=0.433+0.165 \mathrm{UE}$.

Model 2 explains the regression results of earnings response and voluntary disclosure score (VD score) with the coefficient of VD Score $c=0.077$, t-statistic $=0.116$ and $\mathrm{p}$-value $=0.908$. The regression results are not significant. There is also a positive relationship between earnings response and voluntary disclosure score, consistent with that of Gelb and Zarowin (2000), Widiastuti (2002) and Adhariani (2005). The Rsquare of model 2 is 0.000 which implies that voluntary disclosure score (VD score) has no effect on earnings response. Hence, the regression equation for model 2 is $\mathrm{R}=0.455+0.077$ VD SCORE.

Model 3 expresses the regression results of earnings response to unexpected earning (UE) and voluntary disclosure score (VD score). The coefficient of unexpected earning (UE) $b=0.173$, t-statistic $=2.522$ and $\mathrm{p}$-value $=0.018$, and the results are significant, similar to that of model 1 . Also, there is no significant relationship between earnings response and voluntary disclosure score $(c=0.376$, t-statistic $=0.607$ and $p$ value $=0.549)$. There is a positive relationship between earnings response on unexpected earning (UE) and voluntary disclosure score (VD score). The R-square of model 3 is 0.191 which implies that the effect of unexpected earning (UE) and voluntary disclosure score (VD score) on earnings response is $19.1 \%$ which is the highest in all models. Therefore, the final regression equation for model 3 is $\mathrm{R}=0.261+0.173 \mathrm{UE}+$ 0.376 VD SCORE. Only F-statistic of models 1 and 2 are significant at 0.019 and 0.057 respectively. The Durbin-Watson values between 2.427 to 2.463 means that no autocorrelation was noted. The value of Variance Inflation Factor (VIF) between 1.000 to 1.038 means that no multicollinearity has occurred. Overall, we reject the null hypothesis $\mathrm{H}_{0} 1$ and conclude that there is a significant relationship between voluntary disclosure and earnings response.

As conclusion, it can be summarised that the voluntary disclosure score adopted by Botosan (1997) has positive effect on earning response coefficient (ERC) with regression coefficient 0.376. It means the greater voluntary disclosure score results the greater earning response coefficient (ERC). This suggested that the increasing of voluntary disclosure by $1 \%$ will result the increasing of earnings response coefficient (ERC) to $0.376 \%$. And the unexpected earnings have a significant positive effect on earnings response coefficient (ERC). It can explain that expected voluntary disclosure affect to investor reaction.

\subsection{Controlling for Profitability, Size and Leverage}

Refer to the linear regression model that developed to test the effect of voluntary disclosure and company performance on earnings response.. The dependent variable is return (R) and the independent variables are unexpected earnings (UE), voluntary disclosure score (VD Score) and company performance which are profitability, leverage and size of company: as control variables.

From the Table 3 below model 1, 2, 3, 4 and 5 presents the regression which regress one independent variable at each time, however, model 6 is the final regression which includes all the independent variables. From model 1 indicates the coefficient of unexpected earning (UE) with $b=0.165$, t-statistic $=2.479$ and p-value $=0.019$ is significant for regression results of earnings response and unexpected earning (UE). It means there is a positive relationship between earnings response and unexpected earning (UE). The Rsquare of model 1 is 0.180 which imply that the effect of unexpected earning (UE) on earnings response is $18 \%$. Thus, the regression equation for model 1 is $\mathrm{R}=0.433+0.165 \mathrm{UE}$. 
Table 2: Regression results for earnings response on unexpected earning (UE) and voluntary disclosure score (VD score)

\begin{tabular}{lrrr}
\hline Independent variables & Model & Model & Model \\
& $\mathbf{1}$ & $\mathbf{2}$ & $\mathbf{3}$ \\
\hline Constant & 0.433 & 0.455 & 0.261 \\
a & 5.862 & 1.475 & 0.889 \\
& $0.000^{* *}$ & 0.151 & 0.382 \\
UE & 0.165 & & 0.173 \\
b & 2.479 & & 2.522 \\
& $0.019^{*}$ & & $0.018^{*}$
\end{tabular}

$\begin{array}{llll}\text { VD SCORE } & & 0.077 & 0.376 \\ \text { c } & & 0.116 & 0.607 \\ & & 0.908 & 0.549 \\ \text { R-square } & 0.180 & 0.000 & 0.191\end{array}$

$\begin{array}{lrrr}\text { F-statistic } & 6.147 & 0.014 & 3.189 \\ & 0.019^{*} & 0.908 & 0.057^{*} \\ \text { Durbin-Watson } & 2.576 & 2.427 & 2.463\end{array}$

\begin{tabular}{llll} 
VIF & 1.000 & 1.000 & 1.038 \\
Condition Index & 1.381 & 7.843 & 8.358 \\
\hline
\end{tabular}

$\mathrm{UE}=$ unexpected earnings; VD SCORE $=$ voluntary disclosure score Note: $* \mathrm{p}=0.05, * * \mathrm{p}=0.001$

Model 2 explains regression results of earnings response and voluntary disclosure score (VD score) with coefficient of VD Score $c=0.077$, t-statistic $=0.116$ and $\mathrm{p}$-value $=0.908$ is not significant. There also a positive relationship between earnings response and voluntary disclosure score consistent with Gelb and Zarowin (2000), Widiastuti (2002) and Adhariani (2005). The R-square of model 2 is 0.000 which imply that there is not effect of voluntary disclosure score (VD score) on earnings response. Hence, the regression equation for model 2 is $\mathrm{R}=0.455+0.077$ VD SCORE.

Model 3 exhibits regression results of earnings response and profitability with coefficient of profitability $d=2.629$, t-statistic $=3.201$ and $p$-value $=0.003$ is significant. There is a positive relationship between earnings response and profitability. The R-square of model 3 is 0.268 which imply that the effect of profitability on earnings response is $26.8 \%$. So, the regression equation for model 3 is $R=0.274+2.629$ PROFIT.

Model 4 displays regression results of earnings response and leverage with coefficient of leverage $\mathrm{e}=$ -0.016 , t-statistic $=-0.067$ and $\mathrm{p}$-value $=0.947$ is not significant. There is a negative relationship between earnings response and leverage. The R-square of model 4 is 0.000 which imply that there is not effect of leverage on earnings response. So, the regression equation for model 4 is $R=0.488-0.016 \mathrm{LEV}$.

Model 5 shows regression results of earnings response and size of company with coefficient of size of company $\mathrm{f}=0.147$, $\mathrm{t}$-statistic $=1.208$ and $\mathrm{p}$-value $=0.237$ is not significant. There is a positive relationship 
between earnings response and size of company consistent. The R-square of model 5 is 0.049 which imply that the effect of size of company on earnings response is $4.9 \%$. Consistent with Freeman 1987, Chaney and Jeter 1993, Fama and French 1993 size of company effect on the earnings response coefficient (ERC). So, the final regression equation for model 5 is $R=-0.336+0.147$ SIZE.

Model 6 expresses regression results of voluntary disclosure and company performance on earnings response. The coefficient of unexpected earning (UE) $b=0.142$, $\mathrm{t}$-statistic $\quad=2.087$ and $\mathrm{p}$-value $=$ 0.048 ; and the coefficient of profitability $\mathrm{d}=1.805$, $\mathrm{t}$-statistic $=2.032$ and $\mathrm{p}$-value $=0.053$ are significant same as model 1 and 3 . And there is not significant between earnings response and voluntary disclosure score $(\mathrm{c}=0.139$, $\mathrm{t}$-statistic $=0.203$ and $\mathrm{p}$-value $=0.841)$; earnings response and leverage $(\mathrm{e}=-0.099, \mathrm{t}$ statistic $=-0.454$ and $p$-value $=0.654)$; and earnings response and size of company $(f=0.190, t$-statistic $=$ 1.391 and $\quad p$-value $=0.177)$. There also a positive relationship between earnings response on unexpected earning (UE); and earnings response on profitability. The R-square of model 6 is 0.403 which imply that the effect of unexpected earning (UE), voluntary disclosure score (VD score), profitability, leverage and size of company on earnings response is $40.3 \%$ which is the highest in all models. Therefore, the final regression equation for model 6 is $\mathrm{R}=-0.723+0.142 \mathrm{UE}+0.139 \mathrm{VD}$ SCORE + 1.805 PROFIT 0.099 LEV + 0.190 SIZE.

Only F-statistic of model 1, 3 and 6 are significant level with $0.019,0.019$ and 0.022 respectively. The Durbin-Watson values that get between 2.065 to 2.576 are no autocorrelation symptom. The value of Variance Inflation Factor (VIF) between 1.000 to 1.720 mean there is no multicollinearity occurred. As overall, we reject null hypothesis $\mathrm{H}_{0}$ and conclude that there is a significant relationship with earnings response.

As conclusion, it can be summarised that voluntary disclosure has a positive effect on earning response coefficient (ERC) with a regression coefficient of 0.139 . This means that a greater voluntary disclosure score results in a higher earning response coefficient (ERC). This also suggests that the increase of voluntary disclosure by $1 \%$ will result in the increase of earnings response coefficient (ERC) by $0.139 \%$; however the statistic is not significant. Nevertheless, profitability has a significant positive effect on earning response coefficient (ERC) and unexpected earnings also have a significant positive effect on the same. Meanwhile, leverage has a negative effect on earning response coefficient (ERC) whereas the size of company has a positive effect on earning response coefficient (ERC). This is consistent with prior research which also indicated that the larger the size of the company, the more comprehensive disclosure made, which reduces the impact of investor reaction towards unexpected earnings.

\subsection{Assumptions Testing}

Durbin-Watson is using to test for autocorrelation. Usually Durbin-Watson is between 0 and 4. If DurbinWatson value is 2.5 , this means that there is no autocorrelation symptom in the sample. The Variance Inflation Factor (VIF) is used to test for multicollinearity within the set of independent variables. If Variance Inflation Factor (VIF) value is less than 5, this means that no multicollinearity has occurred; in contrast, multicollinearity has occurred if the Variance Inflation Factor (VIF) value is more than 5.

Table 3: Regression results for voluntary disclosure and company performance on earnings response 


\begin{tabular}{lrrrrrr}
\hline $\begin{array}{l}\text { Independent } \\
\text { variable }\end{array}$ & $\begin{array}{rrrr}\text { Model } \\
\mathbf{1}\end{array}$ & $\begin{array}{r}\text { Model } \\
\mathbf{2}\end{array}$ & $\begin{array}{r}\text { Model } \\
\mathbf{3}\end{array}$ & $\begin{array}{r}\text { Model } \\
\mathbf{4}\end{array}$ & $\begin{array}{r}\text { Model } \\
\mathbf{5}\end{array}$ & $\begin{array}{r}\text { Model } \\
\mathbf{6}\end{array}$ \\
\hline Constant & 0.433 & 0.455 & 0.274 & 0.488 & -0.336 & -0.723 \\
a & 5.862 & 1.475 & 2.891 & 6.009 & -0.488 & -1.095 \\
& $0.000^{* *}$ & 0.151 & $0.007^{*}$ & $0.000^{* *}$ & 0.629 & 0.284 \\
UE & 0.165 & & & & & 0.142 \\
b & 2.479 & & & & & 2.087 \\
& $0.019 *$ & & & & & $0.048^{*}$
\end{tabular}

$\begin{array}{lrrr}\text { VD SCORE } & 0.077 & & 0.139 \\ \text { c } & 0.116 & & 0.203 \\ & 0.908 & & 0.841 \\ \text { PROFIT } & & 2.629 & 1.805 \\ \text { d } & & 3.201 & 2.032 \\ & & 0.003^{*} & 0.053^{*}\end{array}$

\begin{tabular}{|c|c|c|c|c|c|c|}
\hline LEV & & & & -0.016 & & -0.099 \\
\hline e & & & & -0.067 & & -0.454 \\
\hline & & & & 0.947 & & 0.654 \\
\hline SIZE & & & & & 0.147 & 0.19 \\
\hline f & & & & & 1.208 & 1.391 \\
\hline & & & & & 0.237 & 0.177 \\
\hline R-square & 0.180 & 0.000 & 0.268 & 0.000 & 0.049 & 0.403 \\
\hline F-statistic & 6.147 & 0.014 & 10.248 & 0.005 & 1.458 & 3.243 \\
\hline & $0.019 *$ & 0.908 & $0.019 *$ & 0.947 & 0.237 & $0.022 *$ \\
\hline Durbin-Watson & 2.576 & 2.427 & 2.331 & 2.441 & 2.274 & 2.065 \\
\hline VIF & 1.000 & 1.000 & 1.000 & 1.000 & 1.000 & $1.233-1.720$ \\
\hline Condition Index & 1.381 & 7.843 & 2.448 & 1.366 & 18.168 & 30.175 \\
\hline
\end{tabular}

$\mathrm{UE}=$ unexpected earnings; VD SCORE = voluntary disclosure score; PROFIT = profitability; LEV = leverage; SIZE = size of company

Note: $* \mathrm{p}=0.05, * * \mathrm{p}=0.001$

\section{CONCLUSION}


This study examined the effect of voluntary disclosure on earnings response, using data from 30 companies selected from the construction, consumer product, industrial product, trading or services and properties industries in the Main Market of Bursa Malaysia from 2009 to 2013. Data collected were based on the annual reports. Two sets of regression models were developed to examine the study objective. The effect of voluntary disclosure on earnings response, the effect of voluntary disclosure on company performance and the effect of voluntary disclosure and company performance on earnings response, controlling for profitability, size and leverage, were examined.

Based on the regression analysis, voluntary disclosure (measured using the voluntary disclosure index adopted by Botosan (1997) has a positive effect on earning response coefficient (ERC). Unexpected earnings also has a significant positive effect on earnings response coefficient (ERC). The findings explain the effect of expected voluntary disclosure on investor reaction.

The results also indicate that the voluntary disclosure score adopted by Botosan (1997) has a positive effect on earning response coefficient (ERC) after controlling for profitability, leverage and size. Profitability has a significant positive effect on earning response coefficient (ERC) because of the better performance of company; the company would generally like to disclose more complete information in order to avoid undervaluation of the company's shares; unexpected earnings also have a significant positive effect on earnings response coefficient (ERC). Meanwhile, leverage has a negative effect on earning response coefficient (ERC) whereas the size of the company has a positive effect on earning response coefficient (ERC). In other words, large companies provide more detailed disclosure to reduce the impact of investor reaction to unexpected earnings. 


\section{REFERENCES}

Ariff M. and Cheng Fan Fah. (2013). Earnings Response Coefficients of OECD Banks : Test Extended to Include Bank Risk Factors. Advances in Accounting, Incorporating Advances in International Accounting, Vol 34, 1-:11.

Ariff M., Cheng Fan Fah and Soh Wei Nei (2011) Accounting Earnings Response Coefficient: Extension to Bank Shares. Advances in Accounting Incorporating Advances in International Accounting. Vol 27-2, 346-354.

Botosan. (1997). Disclosure Level and the Cost of Equity Capital. The Accounting Review, 72(3): 323-339. Batosan. (2000). Disclosure Level and Expected Cost of Equity Capital: An Examination of Analysts' Rangkings of Corporate Disclosure and Alternative Methods of Estimating Expected Cost of Equity Capital. Social Science Research Network Electronic Paper Collection.

Cho, J. Y., \& K. Jung. (1991). Earnings Response Coefficients: A Synthesis of Theory and Empirical Evidence. Journal of Accounting Literature, 10: 85-116.

Chow, C. W. and Wong-Boren, A. (1987). Voluntary Financial Disclosure by Mexican Corporations. The Accounting Review LXII (3): 533-541.

Cooke, T. E. (1989). Disclosure in the Corporate Annual Reports of Swedish Companies. Accounting and Business Research, 19(74): 113-124.

Cooke, T. E. (1992). The Impact of Size, Stock Market Listing and Industry Type on Disclosure in the Annual Reports of Japanese Listed Corporation. Accounting and Business Research, 22(87): 229-237.

Lang, M., \& Lundholm, R. (1993). Cross Sectional Determinants of Analyst Ratings of Corporate Disclosures. Journal of Accounting Research, 31(2): 248-271.

Lang, M., \& Lundholm, R. (1996). Corporate Disclosure Policy and Analyst Behaviour. Accounting Review, 71(4): 467-492.

Lev, B., \& Zarowin, P. (1999). The Boundaries of Financial Reporting and How to extend them. Journal of Accounting Research, 37(2): 353-385.

Meek. (1995). Factors Influencing Voluntary Annual Report Disclosures by U.S, U.K, and continental European Multinational Corporations. Journal of International Business Studies. ( $3^{\text {rd }}$ Quarter): 70-82.

Prencipe, A. (2004). Proprietary Costs and Determinants of Voluntary Segment Disclosure: Evidence from Italian Listed Companies. European Accounting Review, 13(2): 319-340.

Raffournier, B. (1995). The Determinants of Voluntary Financial Disclosure by Swiss Listed Companies. The European Accounting, 4(2): 261-280.

Singhvi, S. S. and Desai, H. B. (1971). An Empirical Analysis of the Quality of Corporate Financial Disclosure. The Accounting Review XLVI(1): 129-138.

Wallace, R., Naser, K., \& Mora, A. (1994). The Relationship between the Comprehensiveness of Corporate Annual Reports and Firm Characteristics in Spain. Accounting and Business Research: 41-53.

Wallace, R., Naser, K. (1995). Firm Specific Determinants of the Comprehensiveness of Mandatory Disclosure in the Corporate Annual Reports of Firms Listed on the Stock Exchange of Hong Kong. Journal of Accounting and Public Policy, 14(4): 311-368.

Zeghal, D., Mouelhi, R., \& Louati, H. (2007). An Analysis of the Determinants of Research and Development Voluntary Disclosure by Canadian Firms. The Irish Accounting Review, 14(2): 61-89.

Corresponding Author: Cheng Fan Fah can be contacted at chengfanfah@yahoo.com 